\title{
CORRELATION BETWEEN HUMAN MILK COMPOSITION AND MATERNAL NUTRITIONAL STATUS*
}

\author{
Agnieszka Bzikowskal, Aneta Czerwonogrodzka-Senczyna ${ }^{1}$, Halina Weker ${ }^{1}$, Aleksandra Wesołowska \\ ${ }^{1}$ Medical University of Warsaw, Faculty of Health Science, Department of Clinical Dietetics, Poland \\ ${ }^{2}$ Medical University of Warsaw, Regional Human in Holy Family Hospital, Department of Neonatology, \\ Laboratory of Human Milk and Lactation Research, Warsaw, Poland
}

\begin{abstract}
Background: Human milk is the optimal nutrition for newborns and infants during the first period of their life - from birth to 6-th month. It contains a uniquely quantitative and qualitative balanced nutrients profile. Composition of breast milk is dynamic and may vary according to maternal nutritional status.

Objective: The aim of this study was to investigate associations between human milk composition and maternal nutritional status.

Material and methods: One-day milk samples were provided by exclusively breastfeeding mothers $(n=40)$ at the first month of lactation. Protein - total and true, fat, carbohydrate, dry matter and energy content were determined using the Human Milk Analyzer by MIRIS. The anthropometric measurements (current body weight, height) were used to calculate current body mass index (BMI). On this basis, we assessed nutritional status of examined population.

Results: For the majority of women $(75 \%, \mathrm{n}=30)$ currently BMI value was in range of $18.5-24.9 \mathrm{~kg} / \mathrm{m}^{2}$, for the rest of women it was $\geq 25 \mathrm{~kg} / \mathrm{m}^{2}$. The median macronutrient composition per $100 \mathrm{ml}$ of mature breast milk was $7.0 \mathrm{~g}$ for carbohydrate, $1.1 \mathrm{~g}$ for protein, $3.5 \mathrm{~g}$ for fat, 11.9 for dry matter and energy content was $66.0 \mathrm{kcal}$. Maternal body mass index was positively related to lipid, dry matter and energy breast milk content $(\mathrm{p}<0.05)$.

Conclusions: The majority of examined women in the first month of lactation was in normal state of nutrition. For the rest of women BMI values indicated for overweight. Our results confirm correlation between human milk composition and maternal nutritional status, especially in matters of energy value and fat content in human milk.
\end{abstract}

Key words: breastfeeding, body mass index (BMI), human milk composition, macronutrients

\section{STRESZCZENIE}

Wprowadzenie: Mleko kobiece jest jedynym optymalnym pokarmem dla noworodków i niemowląt od chwili urodzenia do ukończenia 6 miesiąca życia. Unikalność pokarmu kobiecego wynika z idealnie dobranej ilościowo i jakościowo kompozycji składników. Skład mleka kobiecego jest dynamiczny i może się różnić w zależności od stanu odżywienia kobiety karmiącej.

Cel: Celem badania była analiza zależności między składem mleka kobiecego a stanem odżywienia kobiety karmiącej piersią.

Materiał i metody: Próbki mleka pochodzące z dobowej zbiórki mleka zostały dostarczone przez 40 zdrowych kobiet karmiących dzieci wyłącznie. Badanie prowadzono w pierwszym miesiącu laktacji. W otrzymanym materiale oznaczono zawartość białka całkowitego i białka odżywczego, tłuszczu, węglowodanów, suchej masy oraz wartość energetyczną, używając analizatora składu mleka (HMA MIRIS). Aktualny wskaźnik masy ciała BMI badanej populacji został wyliczony na podstawie dokonanych pomiarów antropometrycznych (masa i wysokość ciała). Na tej podstawie oceniono stan odżywienia matek karmiących piersią uczestniczących w badaniu.

Wyniki: Dla 30 kobiet (75\%) BMI mieściło się w zakresie 18.5-24.9 kg/m², dla pozostałych (25\%) przekraczało $25.0 \mathrm{~kg} /$ $\mathrm{m}^{2}$. Mediana zawartości makroskładników w mleku kobiecym wynosiła dla białka $-1.1 \mathrm{~g} / 100 \mathrm{ml}$, dla węglowodanów 7.0 $\mathrm{g} / 100 \mathrm{ml}$, dla tłuszczu $3.5 \mathrm{~g} / 100 \mathrm{ml}$, dla suchej masy $11.9 \mathrm{~g} / 100 \mathrm{ml}$ i dla wartości energetycznej $66.0 \mathrm{kcal} / 100 \mathrm{ml}$. Wartość wskaźnika BMI dodatnio korelowała z zawartością tłuszczu, suchej masy i wartością energetyczną mleka kobiecego $(\mathrm{p}<0.05)$.

\footnotetext{
This work was supported by the Polish Society of Clinical Child Nutrition research grant obtained at 2015 for project entitled "Association between human milk composition and the nutritional status and body composition of lactating women."
}

Corresponding author: Agnieszka Bzikowska, Warszawski Uniwersytet Medyczny, Wydział Nauk o Zdrowiu, Zakład Dietetyki Klinicznej, Ul. Erazma Ciołka 27, 01-445 Warszawa, tel. +48 509-015-330, e-mail: nzv@wum.edu.pl lub agnieszkabzikowska@gmail.com 
Wnioski: Większość uczestniczek badania charakteryzowała się prawidłowym stanem odżywienia ocenianym w pierwszym miesiącu po porodzie. U pozostałej części wartości wskaźnika BMI wskazywały na nadmiar masy ciała. Uzyskane wyniki potwierdzają zależność wartości odżywczej mleka kobiecego od stanu odżywienia matki, szczególnie w zakresie wartości energetycznej i zawartości tłuszczu.

Słowa kluczowe: karmienie piersia, wskaźnik masy ciata (BMI), skład mleka kobiecego, makroskładniki

\section{INTRODUCTION}

The World Health Organization (WHO) recommends exclusive breastfeeding during the first 6 months of life [27]. Breastfeeding benefits of infants' health are well documented, especially in term of prevention of some diseases (eg. asthma, type 1 diabetes, allerigies) [1]. Human milk provided by healthy, well-nourished mothers is the optimal nutrition for infants as it contains a uniquely balanced profile not only for macronutrients, but also for micronutrients, antibodies, hormones and bioactive molecules $[3,18]$. All components support the nutritional needs, immunoprotection, appropriate growth and physiological development of the infant $[9,15]$.

The nutritional value of human milk composition may vary individually and depends on lactation phase, time of day and night, duration of sucking the breast in individual feeding or time of pumping session. Its composition is dynamic and the nutritional status of breastfeeding mother may also affect energy density and contents of individual nutrients [22,28]. Taking care of healthy nutritional status of breastfeeding women is especially important in regard to a metabolic programming revealed [4].

Body mass index (BMI) is one of the is widely used parameter for assessing nutritional status that correlate with body composition measurements. We have taken the opportunity to analysis the nutritional value of milk by HMA MIRIS and investigated associations between maternal nutritional status assessed by BMI and human milk composition

\section{MATERIAL AND METHODS}

The study was carried out among breastfeeding women $(n=40)$ at first month (3-4 week) of lactation in a maternity department in Warsaw. The inclusion criteria were: age $\geq 18$ years, full-term pregnancy ( $\geq$ 37 weeks) and exclusively breastfeeding. Exclusion criteria included: pre-existing chronic or gestational diseases, smoking during pregnancy, twin pregnancy and low birth weight. Current body weight and height were measured using measurement station and column scales Seca $799( \pm 0.1 \mathrm{~kg} / \mathrm{cm})$. All participants were also asked about pre-pregnancy anthropometric parameters (height and pre-pregnancy body weight) and weight gain during pregnancy. Current and pre- pregnancy body mass index (BMI) was calculated as the ratio between the body weight and the square of the height $\left(\mathrm{kg} / \mathrm{m}^{2}\right)$. Collection and interpretation of this data followed the classification proposed by the World Health Organization (WHO).

Human milk samples (mature milk) were collected 24 hours a day at four time periods: 6.00$12.00,12.00-18.00,18.00-24.00,24.00-6.00$ to minimise possible circadian influences on the milk composition. Pre-feed and post-feed milk samples $(\sim 5-10 \mathrm{ml}$ each) were obtained from the breast (s) the infant fed from, by pumping or by hand expression. Before analysis each sample was warmed at $40^{\circ} \mathrm{C}$ and homogenized for $1,5 \mathrm{~s} / 1 \mathrm{ml}$ of probe using Sonicator (Milk Homogeniser MIRIS, Uppsala, Sweden). Human milk was analysed using MIRIS human milk analyser (HMA MIRIS, Uppsala, Sweden) according to the manufacturer's recommendation. Working principle of this device is based on mid-infrared transmission spectroscopy. Protein - total and true, lipid, carbohydrate, energy and dry matter content were determined in each sample in three times. As the result we use the average of three measurements. Concentrations of all macronutrients (fat, carbohydrates, protein - total and true) were reported in grams per $100 \mathrm{ml}$ and energy (kilocalories) was calculated at $9 \mathrm{kcal} / \mathrm{g}$ for fat, $4 \mathrm{kcal} / \mathrm{g}$ for protein, and $4 \mathrm{kcal} / \mathrm{g}$ for carbohydrates. Total protein refers to total nitrogen $\times 6.25$ and true protein is total protein minus $24 \%$ for no protein nitrogen. Total protein, as reported by the MIRIS analyser, was converted to bioavailable protein for data analysis using the following equation: total protein $($ grams $) \times 0.825[10,13]$.

For all tests, $\mathrm{p}<0.05$ was considered as significant. All data were assessed for normality. To assess the difference between current and pre-pregnancy BMI we used the Wilcoxon signed rank test. Correlation between BMI and human milk components were assessed using Spearman's rank correlation coefficient. The statistical analysis was performed with Statistica software (version 10.0 PL).

\section{RESULTS}

The descriptive characteristic of the study population $(n=40)$ is shown in Table 1. Median maternal age was 29.5 years. Median values of BMI - current and pre-pregnancy were $22.8 \mathrm{~kg} / \mathrm{m}^{2}$ and $21.22 \mathrm{~kg} / \mathrm{m}^{2}$, respectively. For the majority of women $(75 \%, n=30)$ 
currently BMI value was in range of $18.5-24.9 \mathrm{~kg} / \mathrm{m}^{2}$, for the rest of women it was $\geq 25 \mathrm{~kg} / \mathrm{m}^{2}$. According to pre-pregnancy BMI the results were similar - $85 \%$ of women $(n=33)$ had BMI value in range of 18.5-24.9 $\mathrm{kg} / \mathrm{m}^{2}$, the rest one $\geq 25 \mathrm{~kg} / \mathrm{m}^{2}$. However, there was statistically significant difference between current and pre-pregnancy BMI. The Wilcoxon signed rank test was 3.54, $p=0.0004(p<0.05)$.

Table 1. Characteristics of examined population, $n=40$.

\begin{tabular}{|c|c|c|}
\hline & Median & Interquartile range \\
\hline Age (years) & 29.5 & $27.0-32.5$ \\
\hline Current body weight $(\mathrm{kg})$ & 63.9 & $54.75-72.30$ \\
\hline Height $(\mathrm{cm})$ & 165.5 & $161.0-172.5$ \\
\hline Current BMI $\left(\mathrm{kg} / \mathrm{m}^{2}\right)^{*}$ & 22.8 & $20.07-26.48$ \\
\hline Pre-pregnancy body weight $(\mathrm{kg})$ & 58.0 & $53.75-69.0$ \\
\hline Pre-pregnancy BMI $\left(\mathrm{kg} / \mathrm{m}^{2}\right)^{*}$ & 21.22 & $19.49-23.71$ \\
\hline Total body gain during pregnancy $(\mathrm{kg})$ & 14.0 & $12.0-16.5$ \\
\hline
\end{tabular}

${ }^{*}$ Statistically significant difference between current and pre-pregnancy BMI; Wilcoxon signed rank test: 3.54, $\mathrm{p}=0.0004$ ( $\left.\mathrm{p}<0.05\right)$.

Table 2 provides average results of nutritional value of human milk (energy, macronutrients and dry matter) in given population. The median milk energy

content was $66 \mathrm{kcal} / 100 \mathrm{ml}$ (interquartile range: 62.0 $72.5 \mathrm{kcal} / 100 \mathrm{ml})$.

Table 2. Composition of human milk, $\mathrm{n}=40$.

\begin{tabular}{|c|c|c|}
\hline & Median & Interquartile range \\
\hline Energy $(\mathrm{kcal} / 100 \mathrm{ml})$ & 66.0 & $62.0-72.5$ \\
\hline Fat $(\mathrm{g} / 100 \mathrm{ml})$ & 3.5 & $3.0-4.1$ \\
\hline Total protein $(\mathrm{g} / 100 \mathrm{ml})$ & 1.1 & $0.8-1.0$ \\
\hline True protein $(\mathrm{g} / 100 \mathrm{ml})$ & 0.9 & $1.07-1.3$ \\
\hline Carbohydrates $(\mathrm{g} / 100 \mathrm{ml})$ & 7.0 & $6.9-7.3$ \\
\hline Dry matter $(\mathrm{g} / 100 \mathrm{ml})$ & 11.9 & $11.2-12.7$ \\
\hline
\end{tabular}

We do not observed associations between maternal BMI (current and pre-pregnancy) and macronutrients content such as: protein (total and true) and carbohydrates using Spearman's rank correlation coefficient. Simultaneously, we reported that BMI was positively correlated with energy, fat and dry matter content in human milk. Statistically significant differences were indicated by asterisk in Table 3 .

Table 3. Spearman rank correlation coefficient between maternal BMI and milk components.

\begin{tabular}{|c|c|c|c|c|}
\hline & \multicolumn{2}{|c|}{ Current BMI } & \multicolumn{2}{c|}{ Pre - pregnancy BMI } \\
\hline & R Spearman & $\mathrm{p}$ value & R Spearman & value \\
\hline Energy & 0.39 & $0.01^{*}$ & 0.33 & $0.04^{*}$ \\
\hline Fat & 0.37 & $0.02^{*}$ & 0.30 & $0.01^{*}$ \\
\hline Total protein & 0.27 & 0.09 & 0.24 & 0.16 \\
\hline True protein & 0.16 & 0.32 & 0.23 & 0.13 \\
\hline Carbohydrates & 0.02 & 0.91 & 0.03 & 0.87 \\
\hline Dry matter & 0.41 & $0.00^{*}$ & 0.39 & $0.01^{*}$ \\
\hline
\end{tabular}

- statistically significant differences

\section{DISCUSSION}

A key element enabling optimal growth and development of new-borns and infants is to provide them adequate supply of energy and nutrients. Knowledge regarding variability of human milk composition is extremely important in order to optimise infant feeding [22].

Sampling protocols are of prime importance when investigating association between HM component and maternal nutritional status. Many interpretations of the content of human milk were based on spot samples from multiple donors at different stages of lactation. Daytime consumption of milk in a given infant varies between $46 \%$ and $58 \%$ of the total 24 -hour consumption, so that reliance on less than a 24-hour sampling may be misleading [28]. In our study, procedure of milk collection (including 24-hours period) was performed to minimise errors. We also confirmed systemic change between pre- and post-feed samples for concentrations of energy and macronutrients. What is more, all of the breast milk samples were from mothers practicing exclusive breastfeeding. 
Analysis of carbohydrates by HMA MIRIS in human milk is cofounded by the presence of lactose and non lactose carbohydrates, mainly human milk oligosaccharides (HMOs) [13]. Some of the discrepancies between the findings for lactose concentrations might be related to the inclusion of HMOs in the mid-infrared (mid-IR) transmission spectroscopy measurements [26]. Since the reference laboratory analysis for lactose concentration - highpressure liquid chromatography (HPLC) does not measure HMOs, it is likely that lactose levels measured by mid-IR transmission spectroscopy were a result of absorbing terminal or core lactose moieties of HMO [5]. The total concentration of HMOs in human milk varies across lactation and decreases from about $2.3 \mathrm{~g} / 100 \mathrm{ml}$ in colostrum to $0.7 \mathrm{~g} / 100 \mathrm{ml}$ in mature milk $[8,11]$. The measured concentrations of carbohydrates in our study was not related to maternal current and pre-pregnancy BMI. This finding is consistent with previous results, which showed that the lactose concentration in HM (measured by enzymatic spectrophotometric method) was not related to maternal adiposity profiles (BMI $\mathrm{p}=0.66$; $\%$ fat mass $-\mathrm{p}=0.48$ ) [17]. Simultaneously, others authors found positive interaction between percentage of fat mass ( $\%$ FM) and the month of lactation, indicating that association between $\% \mathrm{FM}$ and lactose strengthens over the first months of lactation [17]. Despite low variability in lactose content, the total production of this carbohydrates might be reduced in mothers with severe malnutrition [25].

In present study we do not observed correlation between protein concentrations and maternal BMI. The few earlier studies investigating relationships between protein content in human milk and maternal nutritional status are contradictory. Some reporting a positive correlation between protein and maternal adiposity assessed by BMI [2, 7, 12, 21], whereas Quinn et al. [23] and Kugananthan et al. [17] have found that higher percentage of fat mass but not BMI was associated with higher protein concentrations. By contrast, Bachour et al. [2] reported negative association between protein content and BMI.

Fat is known to be the most variable macronutrient in human milk. It has been reported that fat content varies depending on maternal diet [14], morning/night [16], hind- or fore-milk [19] and storage conditions [6]. In our study median fat concentrations in HM were $3.5 \mathrm{~g} / 100$. Our finding was high compared to that in China (3.4 g/100 ml) [29], Japan $(3.56 \mathrm{~g} / 100 \mathrm{ml})$ [20] and US $(3.6 \mathrm{~g} / 100 \mathrm{ml})$ [10]. We observed that human milk energy density was positively correlated with fat concentration, both were positively related to maternal BMI. Previous findings [29] are in line with our findings. They reported that maternal body mass index (BMI) was positively associated with milk fat content, to a greater extent than dietary intake did. All other maternal characteristics were not significant for milk composition. Contrary to previously reported results, Bachour et al. [2] and Quinn et al. [24] suggested that there were no associations between maternal nutritional status and fat concentrations in human milk.

\section{CONCLUSIONS}

The majority of examined women in the first month of lactation was in normal state of nutrition. For the rest of women BMI values indicated for overweight. Our results confirm correlation between human milk composition and maternal nutritional status, especially in matters of energy value and fat content in human milk. These results enhance future studies to explore maternal factors that may be associated with changes in macronutrient content in human milk. All of these efforts will contribute toward achieving optimum health and development in infants.

\section{Acknowledgements}

This work was supported by The Polish Society of Clinical Child Nutrition research grant obtained at 2015 for project titled "Association between human milk composition and the nutritional status and body composition of lactating women."

\section{Conflict of interest}

The authors declare no conflict of interest.

\section{REFERENCES}

1. Agostoni C., Braegger C., Decsi T., Kolacek S., Koletzko B., Kim Fleischer Michaelsen, Mihatsch W., Moreno L.A., Puntis J., Shamir R., Szajewska H., Turck D., Goudoever J.: Breastfeeding: A commentary by the ESPGHAN Committee on Nutrition. J Pediatr Gastroenterol Nutr 2009;49:112-125.

2. Bachour P., Yafawi R., Jaber F., Choueiri E., AbdelRazzak Z.: Effects of smoking, mother's age, body mass index and parity number on lipid, protein and secretory Immunoglobulin A concentrations of human milk. Breastfeeding Med 2012;7(3):179-188.

3. Ballard O., Morrow A.L.: Human milk composition: Nutrients and bioactive factors. Pediatr. Clin North Am 2013;60:49-74.

4. Barker D.J., Bagby S.P., Hanson M.A.: Mechanisms of disease: in utero programming in the pathogenesis of hypertension. Nat Clin Pract Nephrol 2006;2:700 -707.

5. Casadio Y.S., Williams T.M., Lai C.T., Olsson S.E. Hepworth A.R., Hartmann P.E.: Evaluation of a mid-infrared analyzer for the determination of the macronutrient composition of human milk. J Hum Lact 2010;26(4):376-383.

6. Chang Y.C., Chen C.H., Lin M.C.: The macronutrients in human milk change after storage in various containers. Pediatr Neonatol 2012;53:205-209. 
7. Chang N., Ji A.J., Kim H., Sujeong A., Si-Won Lee K., Yi H., Kim J., Yim J.G., Jung B.M.: Macronutrient composition of human milk from Korean mothers of full term infants born at 37-42 gestational weeks. Nutr Res Prac 2015;9(4):433-438.

8. Coppa G.V., Gabrielli O., Pierani P., Catassi C., Carlucci A., Giorgi P.L.: Changes in carbohydrate composition in human milk over 4 months of lactation. Pediatrics 1993;91(3):637-641.

9. Fichter M., Hirschberg D.L., Waldura B., Schofer O., Ehnert S., Schwarz L.K.; Ginneken C.V., Schafer K.H.: Breast milk contains relevant neurotropic factors and cytokines for enteric nervous system development. Mol Nutr Food Res 2011;55:1592-1596.

10. Fomon S.J.: Requirements and recommended dietary intakes of protein during infancy. Pediatr Res 1991;30:391-395.

11. Gabrielli O., Zampini L., Galeazzi T., Padella L., Santoro L., Peila C., Giuliani F., Bertino E., Fabris C., Coppa G.V.: Preterm milk oligosaccharides during the first month of lactation. Pediatrics, 2011;128(6):15201531.

12. Grote V., Verduci E., Scaglioni S., Vecchi F., Contarini G., Giovannini M., Koletzko B., Agostoni C.: Breast milk composition and infant nutrient intakes during the first 12 months of life. Eur J Clin Nutr 2016;70:250256.

13. Groh-Wargo S., Valentic J., Khaira S., Super D.M., Collin M.: Human Milk Analysis Using Mid-Infrared Spectroscopy. Nutr Clin Pract 2016;31(2):266-272.

14. Innis S.M.: Human milk and formula fatty acids. J Pediatr 1992;120:56-61.

15. Isaacs E.B., Fischel B.R., Quinn B.T., Chong W.K., Gadian D.G., Lucas A.: Impact of breast milk on intelligence quotient, brain size and white matter development. Pediatr Res 2010;67:357-362.

16. Kent J.C., Mitoulas L.R., Cregan M.D., Ramsay D.T., Doherty D.A., Hartmann P.E.: Volume and frequency of breastfeedings and fat content of breast milk throughout the day. Pediatrics 2006;117:387-395.

17. Kugananthan S., Gridneva Z., Lai Ch.T., Hepworth A.R., Mark P.J., Kakulas F., Geddes D.T.: Associations between Maternal Body Composition and Appetite Hormones and Macronutrients in Human Milk. Nutrients 2017;9(3).

18. Lonnerdal B.: Breast milk: A truly functional food. Nutrition 2010;16:509-511.
19. Mitoulas L.R., Kent J.C., Cox D.B., Owens R.A., Sherriff J.L., Hartmann P.E.: Variation in fat, lactose and protein in human milk over $24 \mathrm{~h}$ and throughout the first year of lactation. Br J Nutr 2002;88:29-37.

20. Morita A., Yoshiike N., Takimoto H., Tsubota-Utsugi M., Kodama H., Shimizu T., Sugiyama T., Tabata I., Tamai H., Tsutsumi C., Hirahara F., Kuzuya M., Gomi I., Nakamura K., Yoshida H., Nakamura M.: Dietary reference intakes for Japanese 2010: lifestage. J Nutr Sci Vitaminol 2013;59:103-109.

21. Nommsen L.A., Lovelady Ch.A., Heinig M.J., Lönnerdal B., Dewey K.G.: Determinants of energy, protein, lipid and lactose concentrations in human milk during the first 12 month of lactation: the DARLIND14523 Study. Am J Clin Nutr 1991;53:457-465.

22. Orczyk-Pawiłowicz M, Wesołowska A.: Różnice w biochemicznym składzie mleka matek wcześniaków i noworodków urodzonych o czasie - aspekt żywieniowy i terapeutyczny. Standardy Medyczne/Pediatria, 2013;10:677-686.

23. Quinn E.A., Largado F., Borja J.B., Kuzawa C.W.: Maternal characteristics associated with milk leptin content in a sample of filipino women and associations with infant weight for age. J Hum Lact 2015;31:273-281.

24. Quinn E.A., Largado F., Power M., Kuzawa C.W.: Predictors of breast milk macronutrient composition in Filipino mothers. Am J Hum Biol 2012;24(4):533-540.

25. Segura S.A., Ansotegui J.A., Diaz-Gomez N.M.: The importance of maternal nutrition during breastfeeding: Do breastfeeding mothers need nutritional supplements? An Pediatr 2016;84 (6):347-354.

26. Smilowitz J.T., Gho D.S., Mirmiran M., German J.B., Underwood M.A.: Rapid Measurement of Human Milk Macronutrients in the Neonatal Intensive Care Unit: Accuracy and Precision of Fourier Transform MidInfrared Spectroscopy. J Hum Lact 2014;30(2):180-189.

27. World Health Organization: Global strategy for Infant and young children feeding. Geneva, Switzerland 2003.

28. Wojcik K.Y., Rechtman D.J., Lee M.L., MontoyaA., Medo E.T.: Macronutrient analysis of a nationwide sample of donor breast milk. J Am Diet Assoc 2009;109:137-140.

29. Yang T., Zhang Y., Ning Y., You L., Ma D., Zheng Y., Yang $X$., Li W., Wang J., Wang P.: Breast milk macronutrient composition and the associated factors in urban Chinese mothers. Chin Med J 2014;127:1721-1725.

Received: 14.05 .2018

Accepted: 10.09.2018

This article is available in Open Access model and licensed under a Creative Commons Attribution-Non Commercial 3.0.Poland License (CC-BY-NC) available at: http://creativecommons.org/licenses/by-nc/3.0/pl/deed.en 